\title{
POTENTIALS AND PITFALLS OF THE IMPLEMENTATION OF HYBRID LEARNING IN STRUCTURE CLASS IN RELATION TO THE STUDENTS' DIGITAL LITERACY AND LEARNING ACHIEVEMENT
}

\author{
Lungguh Halira Vonti $^{\left.a^{*}\right)}$, Leora Grahadila ${ }^{a)}$ \\ ${ }^{a)}$ Universitas Pakuan, Bogor, Indonesia \\ ${ }^{*}$ Corresponding Author: lungguh@unpak.ac.id
}

Article history: received 08 December 2020; revised 15 December 2020; accepted 26 December 2020

\begin{abstract}
The purpose of this study is to describe the potential and the pitfalls of the implementation of hybrid learning in structure class. The sampling technique used was purposive sampling since there was only one class who experienced hybrid learning in grammar class. The samples were 20 students of class $\mathrm{D}$ from the third semester. The research instrument was a questionnaire and also Focus Group Interview. The research method used is mixed method. The quantitative data is taken from experimental research design and is processed by using SPSS (Statistical Package for Social Science) software version 25.0. the qualitative data is taken from the questionnaire and focus group interview. The results showed the application of hybrid learning affected positively to the students' score in structure class since there is significant increase of their posttest score. Based on the qualitative data, it is shown that the application of hybrid learning model has certain aspects that affect their improvement in structure class. Yet, based on the FGI, the researcher also found out some disadvantages of pitfalls of the implementation of hybrid learning.
\end{abstract}

Keywords: hybrid learning; potential; pitfalls; digital literacy

\section{INTRODUCTION}

In 21st century, most of the students represent the first generation that grow up with new technologies. They are considered as the Z-generation or they are also called as digital natives. They spend their entire lives surrounded by and using computers, videogames, digital music players, video cams, cell phones, and all the other toys and tools of the digital age. In the teaching process, the conventional teaching method by applying face to face teaching learning process are currently set aside by the use of technology. The lecturers now, are getting used to give the material, assignments, as well as receive the students' assignments submission through digital technology such as email or education platforms.

The use of technology in modern teaching and learning process has some benefits, and one of them is to improve students' digital literacy besides the students' achievement. In English study program, the subjects applying blended learning are grammar courses, ICT course, and general courses.

Initially, the term of digital literacy was started by the spread of the use of internet and computer. However, what digital literacy means has changed rapidly and meant different things to different people. At first, digital literacy encompassed many different skills, including the physical ability to type and move a mouse as well as the knowledge of how to use particular software (Warschauer [1]). Hence, the definitions of digital literacy are varied. Many scholars have shifted to consider digital literacy from within a multiliteracies framework. Multiple literacies recognize that literacy comes in many different forms, outside of the written word, and that each of these literacies has unique (though sometimes converging) ways of communicating and decoding meaning [2].

To look back at the history of digital learning, in his research article, (Prensky [3]) differentiated the two generations of learners. The students who are immersed in digital technologies and familiar with them are called digital native, and those who lived in previous era that are called digital immigrant. In more recent studies the argument for technology has developed past the idea of digital natives. The fact is that the society we live in has changed, and the skills and tools our students are taught in school must adapt to reflect what they will need to be successful in the broader world [2].

To adjust the teaching and learning process with the development of technology, many institutions started to apply and combine the offline teaching with the online teaching, or it is commonly called hybrid learning/ blended learning. Blended learning, in general, is the combination of conventional face to face learning process and online learning. In many research articles, the definitions of blended learning are varied. Garrison \& Vaughan [4] define blended learning as "the thoughtful fusion of face-to-face and online learning experiences" emphasizing the need for reflection on traditional approaches and for redesigning learning and teaching in this new terrain. This combination of the teaching learning approaches comes to reflect the weaknesses of the traditional approach and introduces the new design of the approach. While Littlejohn and Pegler [5] also recommend a different approach that they term blended e-learning. This is a useful approach because it changes the focus in learning design by shifting the emphasis from 
simply considering the face-to-face and online environments to that of considering the design issues of (1) introducing elearning and (2) the process of blending (the online and faceto-face environments).

These definitions allow the teachers to have the flexibility of instruction in which they can experiment with the possibilities of a blended learning approach; an approach that combines the effectiveness and socialization opportunities of the classroom with the technology enhanced, active learning possibilities of the online learning environment. However, when the teachers apply the blended learning approach, the conventional role of teachers is still needed. As Graham [6] stated that the use of blended learning still needs to be synchronized and characterized by the human interaction.

Blended learning is basically a learning system that combines conventional learning methods with online learning (through the use of internet facilities / media). Blended learning, which can also be called hybrid learning, is a learning method that allows teachers and students to use technology as a complement to face-to-face learning methods. Rob Hubbart [7] states that Blended Learning is:

\begin{abstract}
Blended Learning is a mixing of different learning environments. It combines traditional face-to-face classroom methods with more modern computer mediated activities. According to its proponents, the strategy creates a more integrated approach for both instructors and learners. Formerly, technologybased materials played a supporting role to face-to-face instruction. (p.91)
\end{abstract}

Based on Rob Hubbert's [7] opinion, blended learning is a combination of face-to-face conventional learning by integrating technology in the form of online learning. Therefore, the implementation of the blended must be directly proportional to the strategies used by both students and lecturers who use the hybrid / blended learning model. The use of technology in the online learning model is a development of learning media that previously used materialbased technology media such as videos and so on.

Graham [6] describes hybrid learning / blended learning as a shift from face-to-face learning characterized by direct interaction to technology and information-based learning that can be done by humans. This opinion is reinforced by the opinion of Mason and Rennie [8] who add that blended learning is a combination of pedagogical, location and technology approaches. Meanwhile, Garrison and Vaughen [4] emphasize the notion of hybrid / blended learning on the need for reflection from conventional or traditional learning processes and the importance of redesigning learning models by combining them with technology.

When we talk about improvement of students' achievement, we need to look back at the definition of achievement itself. In general, student achievement measures the amount of academic material a student learns in a determined length of time. Each subject has learning goals or instructional standards that the lecturers are required to teach. Nana Sudjana [9] defines student learning outcomes as essentially behavior change as a result of learning in a broader sense covering the cognitive field, affective, and psychomotor (p.50). Dimyati and Mudjiono [10] also mentioned learning outcomes is the result of an interaction between learning and teaching (p.200). The learning outcomes or achievement in conclusion is the result of the learning process which ends the teaching process and gives the students information about what they gain through the learning process. achievement or learning outcomes is one of the most important parts of learning. From the teacher's point of view, teaching action ends with the process of evaluating learning outcomes. From the student side, learning outcomes are the end of teaching from the top of the learning process. Every organization certainly carries out a program starting from the planning stage to evaluation [11].

The use of technology yet become major device in the implementation of hybrid learning. Thus, the students and lecturer ability in using technology is also included. This term is also called digital literacy. Initially, the term of digital literacy was started by the spread of the use of the internet and computer. However, what digital literacy means has changed rapidly and meant different things to different people. At first, digital literacy encompassed many different skills, including the physical ability to type and move a mouse as well as the knowledge of how to use particular software (Warschauer [1]. Hence, the definitions of digital literacy are varied. Many scholars have shifted to consider digital literacy from within a multiliteracies framework. Multiple literacies recognize that literacy comes in many different forms, outside of the written word, and that each of these literacies has unique (though sometimes converging) ways of communicating and decoding meaning [2]. To look back at the history of digital learning, in his research article, (Prensky [3]) differentiated the two generations of learners. The students who are immersed in digital technologies and familiar with them are called digital native, and those who lived in previous eras are called digital immigrant. In more recent studies the argument for technology has developed past the idea of digital natives. The fact is that the society we live in has changed, and the skills and tools our students are taught in school must adapt to reflect what they will need to be successful in the broader world [2].

\section{RESEARCH METHODS}

The study aimed at describing the potential and pitfalls found during the teaching process through blended learning. The research method that was employed is mixed method research design. In this research design, the writer gained quantitative data by calculating the students' achievement score after being given the treatment in a form of blended learning. The qualitative data was obtained through the questionnaire and interview conducting to the students and lecturer applying blended learning. After that, the data was analyzed and compared. 
To achieve the study aims, the researchers adopted the experimental approach with two groups' pre-post design (experimental and control). To collect data, the researcher designs the following study instruments and tools: content analysis, achievement test, and a blended learning program in structure course. After collecting the quantitative data, the researcher will employ a qualitative approach by analyzing the questionnaire and interviewing the students and the lecturer. This research was conducted in the fourth semester of the English Language Education Study Program at FKIP, Pakuan University. The number of students registered as active is 75 from 3 classes, yet, the sample of the study was one class since the class has experienced blended learning in structure class. The students were chosen because they used the blended learning method in the teaching and learning process of structure subjects. There are three classes in the second semester, and only one class will be taken as a sample. They are selected purposely because blended learning will be applied only in one class. In conducting the research, COVID 19 plague changed the schedule of the treatment. Since the previous plan of the research was to conduct experimental research design, and the policy did not allow all educational institutions to conduct offline teaching and learning processes, the researchers made some adjustments related to the treatment.

According to the research design, the experimental group would learn the units of the material through the blended learning method while the control group would study the same units in the conventional method. Since the academic year started in February, the class was also started in February 2020. The conventional teaching method, therefore, was held before the COVID 19 plague.

In the first meeting of grammar class at the recurring semester (Sentence Pattern), the students were given placement tests. Therefore, the pretest score was obtained based on the placement test of the class. For the digital literacy pre-test, the lecturer gave the test before the online learning started. The offline teaching sessions should be conducted for 8 meetings. However, because of the COVID 19 plague, the experiment and the data for the research was shortened until March 2020. Starting from April until May, the teaching sessions were conducted online for all classes.

For the qualitative data, the questionnaire then was given to the experimental group by asking the advantages and pitfalls they had during the blended learning model in structure class. The indicators were taken for the variable of their digital literacy and achievement in the class. After that, the focus group interview was conducted to check the validity of the data

\section{RESULTS AND DISCUSSION}

After collecting the data, the research result presented the following points:

\section{A. The Effectiveness of Hybrid Learning}

The Digital Literacy pre-test given was in the form of a digital literacy questionnaire. The questionnaire consists of 4 sections, the first section consists of 5 questions regarding digital related skills, such as web searching skills, operating computers and others. The second part of the questionnaire consists of 8 questions related to self-judging about general skills of digital tools and their uses. The third part deals with the consistency or frequency of using digital tools and it consists of 6 questions. The fourth part consists of 5 questions relating to the students' ability to use digital tools. Here is the tabulation result of digital literacy pre-test.

To answer the first research questions about the effectiveness of blended learning methods, the researchers applied an experimental research method which employed several statistical steps. The first is to find out the difference of the mean of pre test and post test of both control and experimental group.

Table 1. Paired Sample Test

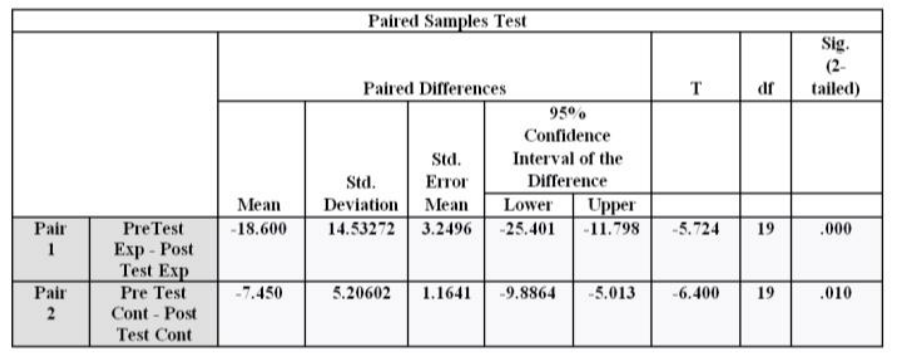

Because the sig results $<0.05$, it can be assumed that there is a difference in the average post-test of the experimental class and the control class. Therefore, we can conclude that the experiment is effective in improving students' grammar achievement and their digital literacy.

Since the model quantitatively has approved that there is significant improvement of students' achievement and their digital literacy, the next step is confirming the value with the students focus group interview about the effectiveness of Hybrid Learning model on their grammar achievement and digital literacy.

\section{B. The Students 'Perceptions of the Implementation of Hybrid Learning toward Their Achievement and Digital Literacy}

After obtaining the quantitative data of the research, to answer the second research question, the researchers gave questionnaires to the sample. The questionnaire was given to the participants of an experimental group related to the score of their post-test after treatments and the causes of the increase of the score. The indicators of the questionnaire are about the ease of use for the web environment (application in online learning), the online learning environment, the subject content and the assessment.

From the data of the questionnaire, it can be seen that for the first indicator about the ease of the use of web environment like the use of online platform, there are 39,8\% of the samples agreed that the online platform used during the implementation of hybrid learning are easy to use regarding the flexibility of the time access of the lesson while $14,3 \%$ of them disagreed to the point. For the second indicator, $39.8 \%$ of the sample agreed and $11.6 \%$ strongly 
agreed that they felt positive toward the online environment offered by the platform. The most positive responses in this indicator is related to the interaction between students $(61,1 \%)$ and lecturer $(55,6 \%)$. They felt that they had more interactions with their friends and lecturer during the implementation of hybrid/blended learning.

Regarding the subject content presented on the online learning platform of the hybrid learning, $31.8 \%$ of the sample agreed positively on some points like they can work out exactly what each lesson on the online class is about $(55.6 \%)$ and that the lessons on the online class are well sequenced $(38,9 \%)$. Yet, in the point of boredom, $27.8 \%$ agreed that they could sense boredom during the implementation of hybrid learning and they thought the content provided in the online platform was not clear and varied $(38,9 \%$ of the sample agreed to this negative statement). The last indicator which stated about the online learning assessment indicated that $44.4 \%$ of the sample were satisfied with the assessment of the learning since they got immediate feedback on the platform.

From the data, we can see that for some points, the students got the improvement of their achievement and digital literacy during the implementation of hybrid learning due to the following aspects:

1) The ease of the use for the web environment; in this point, we can mention some major aspects like the ease of the accessibility of the online platform, the flexibility of the access of the lesson in the online learning platform, and the students' autonomy in learning.

2) The learning environment

Regarding the learning environment, the aspects that mostly affect the students' achievement in structure class as well as their digital literacy is the interactions between the students and between the students and the lecturer. They felt that their interaction can help them in improving their understanding due to the chance to communicate with the lecturers and students. This can be beneficial for those who always hesitate and are not confident enough to ask the lecturers during the offline or conventional class.

3) The subject content

Despite some students who felt that the coverage of the subject content provided in online learning platforms is not really satisfied, the percentage of the sample who have the opposite opinion is still higher. Most of the sample think that they actually repeat the explanation of the subject content of the lesson as many times as they need. It also can be fitted to their own style and pace.

4) The assessment

For the point of assessment, the immediate feedback given in the online platform could really be the positive aspect toward their achievement. Besides it motivates them, it also gives them time to check their result of their learning process.

\section{The Potentials and Pitfalls of the Implementation of Hybrid Learning}

To gain the data for the third research question, the focus group interview was held to see the potentials and pitfalls of the implementation of hybrid learning. The samples who got the highest score of improvement during the implementation of hybrid learning model in structure class were asked several questions in the interview. The indicators used were the same as the previous instruments. Here are the indicators and the questions of the FGI.

Table 2. Indicators for FGI

\begin{tabular}{|c|c|c|}
\hline No & Indicator & Questions \\
\hline 1 & $\begin{array}{l}\text { The ease of use for } \\
\text { the } \\
\text { environment. }\end{array}$ & $\begin{array}{l}\text { 1. Was the website accessible to you at all } \\
\text { times? Explain. }\end{array}$ \\
\hline 2 & $\begin{array}{l}\text { Online learning } \\
\text { environment }\end{array}$ & $\begin{array}{l}\text { 2. What are some of the advantages of online } \\
\text { learning when compared to offline- class } \\
\text { learning? } \\
\text { 3. What are some of the disadvantages of } \\
\text { online learning when compared to offline } \\
\text { class learning? }\end{array}$ \\
\hline 3 & Subject Content & $\begin{array}{l}\text { 4. Do you think that eLearning improved your } \\
\text { results in the Grammar/Structure subject? } \\
\text { Explain } \\
\text { 5. What are some of the features of the } \\
\text { websites (e-learning) which you thought } \\
\text { were beneficial to you as a learner? } \\
\text { Explain. } \\
\text { 6. What are some of the other features which } \\
\text { should be incorporated in the website to } \\
\text { improve learning outcomes? } \\
\text { Do you believe that it is a good idea to } \\
\text { supplement offline class learning with } \\
\text { teacher developed websites such as } \\
\text { eLearning? Explain. }\end{array}$ \\
\hline 4 & Assessment & $\begin{array}{l}\text { 8. What do you think about the lesson } \\
\text { quizzes/assignments? } \\
\text { 9. What do you think about the assessment } \\
\text { given by the lecturer in online learning? }\end{array}$ \\
\hline
\end{tabular}

From the data qualitative analysis above we can draw a conclusion of the potentials and the pitfalls of the implementation of hybrid learning. The potentials are among others related to the:

The ease of use for E-learning, meaning that the website used in online learning is accessible and easy to use.

a. Time management, flexibility, virtual communication, energy-efficient, cost-effective, and many sources availability

b. subject content provided in the website

c. beneficial features in the online learning course, among others content information, video conference, chat or discussion forum, materials (word, video, ppt), and quiz/ assignment

d. Quiz and assignment provided as the assessment are exciting and interesting

e. The assessment given by the lecturer through online learning is predominantly proper for students

Yet, the pitfalls that we can find during the implementation of the hybrid learning are related to the following points:

a. The ease of the use for the web environment; the issue of this point is more related to the internet connection that makes the students sometimes find it a bit difficult to access the website. 
b. Online learning environment;

The points of the pitfalls for this aspect are among others gained from the small numbers of students who stated the following disadvantages:

1) Their confusion of the subject content without direct explanation from the lecturer.

2) The real/direct communication during the class is unlike those they usually have in offline class.

3) Some topics may be more suitable to learn in a face to face session.

4) The boredom of the online sessions they felt during the implementation of hybrid learning

c. Subject content

1) The variation of the learning materials in online sessions need to be developed.

2) The presentation of the subject content is unclear.

\section{CONCLUSION}

Based on the results of the research described in the previous chapter, 3 basic conclusions can be taken that can be used as a reference for further research or used as a reference in the teaching and learning process. The conclusions are as follows:

1. In the process of conducting lectures conducted with hybrid / blended learning models, namely combining conventional learning with online learning, it takes 3 very important stages, namely the preparation stage, the development stage and the implementation stage. In the preparation phase, it is very important for policyholders on campus who will conduct blended lectures to consider the timing of course selection and lecturers who will be able to master blended learning courses. This will be related to the next stage of development. The development phase of blended/hybrid lectures itself can actually take longer than conventional lectures. Lecturers who have hybrid/blended courses must spend time earlier and longer to develop blended lecture content well so that when entering the implementation stage, courses held in a hybrid / blended can run smoothly. This is also related to the readiness of students in carrying out blended/hybrid lectures. It is also important to consider that all students should get training or a brief explanation about blended/hybrid lectures so that when they have to get blended/hybrid courses they are not surprised and can attend the lecture well and smoothly.

2. The findings of quantitative research on the effectiveness of hybrid/blended learning lectures, specifically in English phrase structure (Understanding of English Structure) courses show that there has been a significant increase in the results of their grammar test scores by comparing test results before and after the implementation of lectures in hybrid/blended learning. There is a difference of 22.6 with an increasing trend in post test scores compared to pre-test; thus, after being given the treatment of hybrid/blended learning models, there is a significant positive influence on students' learning outcomes in structure courses.
3. The results of the reported research have been in the concept of digital literacy and have investigated the level of experience and digital literacy before and after the implementation of hybrid/blended learning courses. For qualitative data, this study used and adopted digital literacy questionnaires, which were developed specifically for language learners and became useful instruments in understanding participants' awareness of their digital literacy as well as their use of digital technology and their attitude to the use of technology for language learning. It has the potential to be further developed as a self-assessment and tool that can provide individual user feedback regarding students' digital literacy. For the development of digital literacy in language education, it is recommended that learners should be given practical guidance and opportunities to learn what digital tools and resources are available and how to find and use them for language learning. By improving their digital literacy skills, they will become effective and independent learners and be able to utilize tools and resources for language learning in a real context in their learning process applications.

\section{REFERENCES}

[1] Warschauer, et al. Supporting Digital Literacy in Educational Contexts: Emerging Pedagogies and Technologies. University of California. 2014

[2] McCord, Samantha Shannon. Digital Literacy in the Classroom: Teachers' Attitudes towards Technology and the Language Curriculum. Toronto: University of Toronto. 2015.

[3] Prensky, Marc. Digital Natives, Digital Immigrants. MCB University Press. 2001.

[4] Garrison , Randi \& Norman Vaughan. Blended Learning in Higher Education. San Fransisco: JosseyBass A Wiley Imprint. 2008.

[5] Littlejohn, Allison and Chris Pegler. Preparing for Blended E-Learning. Oxon: Routledge. 2007.

[6] Graham, Charles R. Blended Learning Systems: Definition, Current Trends, And Future Directions. San Fransisco: John Wiley and Son. Inc. 2004.

[7] Hubbart, Rob. 2013. The Really Useful E-learning Instruction Manual: Your Toolkit For Putting Elearning Into Practice. Cheicester: John Wiley \& Sons Ltd. p.91.

[8] Mason, R. \& Rennie, F. 2006. E-learning: The key concepts. London: Routledge.

[9] Sudjana, Nana. 2009. Penilaian Hasil Proses Belajar Mengajar. Bandung: Remaja Rosda Karya.

[10] Dimyati dan Mudjiono. 1999. Belajar dan Pembelajaran. Jakarta: Rineka Cipta. p.200.

[11] N. Karmila and Y. Suchyadi, "Supervisi Pendidikan Di Sekolah Alam Bogor," J. Pendidik. dan Pengajaran Guru Sekol. Dasar, vol. 03, pp. 31-33, 2020. 